\title{
The Influence of Organizational Culture on Employee Performance at Bappeda and Statistics of Bone Regency
}

\author{
Suparman Mekka' ${ }^{1}$ Wahyuddin Hamid², Henni Zainal ${ }^{3}$, Aksa $^{4}$ \\ Universitas Indonesia Timur ${ }^{1,2,3,4}$ \\ Email: suparman.mekka@uit.ac.id ${ }^{1}$,wahyuddinhamid159@gmail.com², henni_zainal@yahoo.com³
}

(Received: 28 July 2020; revised: 14 August 2020; published: 23 September 2020)

\begin{abstract}
Fun work culture create a positive employee attitude and gave impetus to work more diligently and more good.Aims this study was to determine the influence of organizational culture on organizational commitment in Bappeda and Statistics of Bone. Research uses explanatory research with a quantitative approach (positivism). Explanatory research explains the causal relationship between variables that influence the hypothesis. The results show that organizational culture has a significant positive effect on employee performance. This organizational culture can be seen from employee empowerment, team orientation, clarity of vision, direction and organizational goals. The stronger the organizational culture, the higher the performance.
\end{abstract}

Keywords: Organizational Culture, Organizational Commitment, Employee Behavior

Copyright (C) 2020 Universitas Negeri Makassar. This is an open access article under the CC BY license (http://creativecommons.org/licenses/by/4.0/)

\section{INTRODUCTION}

In everyday life, a person cannot be separated from his environment. A person's personality will also be shaped by his / her environment and so that this personality leads to positive attitudes and behaviors, of course, it must be supported by a recognized norm of truth and obeyed as a guide in acting. Basically, humans or someone who is in organizational life tries to determine and form something that can accommodate the interests of all parties, so that in carrying out their activities they do not conflict with the various attitudes and behaviors of each individual. Something that is meant is none other than the culture in which the individual is located, such as values, beliefs, assumptions, hopes and so on (Henni Zainal, Muhammad Rakib, Andi Idham Ashar, Darmawati Manda, Andi Tenry Sose, 2020; Henni Zainal, Parinsi, Indonesia, Hasan, \& Makassar, 2018).

One of the elements that influence employee behavior is the environment, in this case organizational culture. As social beings, employees cannot be separated from various values and norms. Organizational culture can influence how employees behave, how to describe work, how 
to work with colleagues, and how to view the future with broad insights.(Gibson, 2003) states the organizational culture determines what can and cannot be done by members of the organization, determines the normative limits of the behavior of organizational members, determines the nature and form of organizational control and supervision, determines the acceptable managerial style for members of the organization, determines the proper way of working and others etc. In the implementation of work, work culture has a direct effect on work attitudes and determines employee performance. A pleasant work culture makes employee attitudes positive and encourages them to work harder and better. Conversely, if the environmental situation is not pleasant they tend to leave the environment. As stated by Ghiselli and Brown (Tjala, 1989) that work culture affects the quantity and quality of employee work.

Work culture is a philosophy that is based on a view of life as values that become traits, habits and driving forces, entrenched in the life of a group or organization, then reflected in attitudes, behaviors, beliefs, ideals, opinions and actions that are manifested as work or work. Meanwhile, motivation is the driving force that causes a member of the organization to be willing and willing to mobilize abilities in the form of expertise and skills, energy and time to carry out various activities that are their responsibility and which are their obligations, in order to achieve goals, and various pre-determined organizational goals.

According to (Glaser, Susan R; Zamanou, 1987), organizational culture is often described in terms of being shared. Patterns of beliefs, symbols, rituals and myths that develop over time and serve as the glue that holds organizations together. The variety of forms of organizations or companies, of course, has different cultures, this is natural because the organizational environment is different, for example service companies, manufacturing and trading.(Hofstede, 1986), culture is a variety of interactions of habitual characteristics that affect groups of people in their environment. According to (Beach, 1993), culture is at the core of what is important in organizations. Such as giving orders and prohibitions and describing something done and not done that regulates member behavior. So culture contains what may or may not be done so that it can be said to be a guideline used to carry out organizational activities.

Basically, the organizational culture in the company is a tool to unite every individual who carries out activities together.(Kreitner, Robert, Kinicki, 1995)), argued that organizational culture is the social glue that remembers the members of the organization. It seems that in order for different characteristics or personalities between one person and another to be united in an organizational strength, there is a need for social glue. According to (Bliss, 1999), said that in culture there is an agreement that refers to a system of shared meanings, adopted by members of the organization in differentiating one organization from another. Another case with (Robbins, 2003), organizational culture is a shared perception held by members of the organization, and is a shared meaning system. (Kartono, 1983) said that the form of culture that appears in working groups in companies comes from various sources, including: from the stratification of the social class of origin of workers / employees, from technical sources and types of work, the psychological climate of the company itself. created by employers, directors and managers who set the background for the cultural climate of workers in small, informal groups.(Hidayat, 2011), we were all born of human beings and then grew up by social upbringing with culture environment. Since cultures always process plural nation language, tradition and relegion are indispensably diverse. (Molenaa, 2002)), (Kotter, John P. and Heskett, 2002), culture has full 
Suparman Mekka; The Influence of Organizational... |119

power, affects the individual and his performance even on the work environment.(Bucahanan, David; Huncznski, 1997), the elements of organizational or company culture are values, beliefs, opinions, attitudes and norms.

Various actions taken by a person of course vary in the form of behavior. In the organization, the implementation of culture is represented in the form of behavior, meaning that individual behavior in the organization will be colored by the culture of the organization concerned.(Arnold dan Fieldman., 1986), Individual behavior with respect to actual actions carried out by someone can be interpreted that in carrying out one's actions, it will definitely not be separated from their behavior.

\section{RESEARCH METHODS}

This research uses this type of research using an explanatory quantitative approach (positivism). According to (Sugiyono, 2017) explanatory research explains the causal relationship between the variables that influence the hypothesis. This study used two types of data, namely secondary and primary data. The data collection techniques used in this study were questionnaires, observation and documentation. The data analysis technique used in this research is Structural Equation Modeling-Partial Least Squares (SEM-PLS) with the consideration that SEM-PLS can work efficiently with a small sample size with a complex model and is used to analyze reflective and formative measurement models. a situation where the theory is not yet developed (Sholihin dan Ratmono, 2013).

\section{RESEARCH RESULTS AND DISCUSSION}

The calculation results show that organizational culture has a significant positive effect on employee performance. This can be seen from the T-statistic of 5.121 (> 1.96). The original sample estimate value is positive, which is equal to 0.321 which indicates that the direction of the relationship between Organizational Culture and Organizational Commitment is positive. Thus the research hypothesis which states that organizational culture has a significant effect on performance is proven.

The results of the descriptive analysis show that the organizational culture is already going well. One form of organizational culture that is developed is employee empowerment, which is the values of organizational culture that always provide opportunities for employees to develop themselves. Empowerment of employees through providing opportunities has been going well. This opportunity is given by giving full confidence to employees to work in accordance with their respective main duties and avoiding work overlapping. In addition, empowering employees through providing opportunities to make decisions in accordance with their main duties and functions has been going well. This decision-making is related to their duties and functions, both as a leader and as an ordinary staff. Opportunities for employees to make decisions related to work provide great opportunities for employees to be creative in determining ways of working that are more effective and more supportive of achieving organizational goals. Bappeda and Statistics Bone Regency also always provide opportunities and support for employees to continue their education in order to increase the capacity and ability of human resources in preparing general planning documents and technical planning 
documents.

Team orientation is a work culture value that always prioritizes team synergy in carrying out work. The implementation of cooperation at Bappeda and Statistics Regency Bone is quite good. This collaboration is shown in daily work, such as in serving SKPD, each sector coordinates according to the respective SKPD sector within the sphere of Bone Regency government. Communication as part of the team orientation has also been going well. This communication takes place in several ways, namely vertically from top to bottom as well as from bottom to top and horizontally. These ways of communication will greatly affect the effectiveness of communication, because it is very dependent on the communication mechanism itself. The ability to use verbal communication effectively is very important for employees because it allows identification of goals, development of strategies and behaviors to achieve goals. The importance of teamwork in an organization is a must because it is closely related to the ability of employees to jointly achieve organizational goals based on a clear vision, mission, direction and goals.

Vision is a distant view of the organization, the goals of the organization and what must be done to achieve these goals in the future. Bappeda and Statistics Regency Bone have a strong vision, so that they can provide encouragement for employees to achieve goals. The vision of Bappeda and Statistics Regency Bone is "To Become a Professional Institution in Realizing Quality Development Planning and Provision of Accurate Statistical Data"

Achieving the vision provides a clear explanation of what it wants to aim for and also provides information on how the institution works. The vision of Bappeda and the Regency Bone statistics are used as benchmarks in carrying out work. In its operations, people are guided by the mission statement which is the result of compromising the interpretation of the Vision. Mission is something tangible to aim for and can also provide guidelines on how to achieve the Vision. The Mission Statement provides a clear explanation of what it is trying to aim for and sometimes also provides a description of how the institution works. Clear direction and organizational goals are the foundation for employees to achieve organizational goals. The staff of Bappeda and Statistics for Bone Regency have sufficient understanding of the direction of the organization. The direction of the organization contains clues as to what the organization is trying not to violate and is trying to achieve. Directions and objectives as well as activities of Bappeda and Statistics Regency Bone are compiling the Regional Annual Development Plan for Bone Regency; carry out evaluation of the implementation of programs and activities that form the basis for further planning; coordinating local, regional and national development planning, providing data on the results of development implementation; Optimization of regional and sectoral potentials; increasing the professionalism of the planning apparatus.

An understanding of the better the prevailing culture in Bappeda and Bone Regency Statistics employees, the better the employee's performance, and vice versa. The logical consequence of this finding is that all elements involved in the Bappeda organization and the Bone District Statistics should have the same responsibility to build a healthy organizational culture. The healthier the organizational culture will improve the performance of Bappeda employees and Bone Regency Statistics. This is in line with opinion (Hofstede, 1986) (Zainal, Baharuddin, \& Farwita, 2019), that culture is an interaction of habitual characteristics that affect groups of people in their environment. 
Suparman Mekka; The Influence of Organizational... |121

\section{CONCLUSION}

The conclusion in this study is that organizational culture has a significant positive effect on employee performance. This organizational culture can be seen from employee empowerment, team orientation, and clarity of vision, direction and organizational goals. The stronger the organizational culture, the higher the performance. Therefore, organizational cultural values need to be socialized so that they are embedded in each employee's personality. In building an organizational culture, Bappeda and Statistics of Bone Regency must still pay attention to the values contained in the organizational culture construct which consists of: employee empowerment, team orientation, clarity of vision, direction and organizational goals.

\section{BIBLIOGRAPHY}

Arnold dan Fieldman. (1986). Organizational commitment: The utility of an integrative definition. Journal of Applied Psychology, 79.

Beach, L. R. (1993). Making The Right Decision Organiztional Culture, Vision and Planning. USA: Prentice-Hall Inc.

Bliss, W. G. (1999). Why is Corporate Important?. USA: Work force.

Bucahanan, David; Huncznski, A. (1997). Organizational Behavior an Introductory Text. Europe: Prentice Hall.

Gibson, J. . (2003). Struktur Organisasi dan Manajemen. Jakarta: Erlangga.

Glaser, Susan R; Zamanou, S. and H. K. (1987). Measuring and Interpreting Organizational Culture. Management Communication Quartely, 1(2), 173-178.

Henni Zainal, Muhammad Rakib, Andi Idham Ashar, Darmawati Manda, Andi Tenry Sose, I. S. (2020). Strategy of human resources development in improving performance Apparatus in the Bone Regency Regional Inspectorate. Pinisi Business Administration Review, 2(1).

Henni Zainal, U. I. T., Parinsi, W. K., Indonesia, S. P., Hasan, M., \& Makassar, U. N. (2018). The Influence Of Strategic Assets And Market Orientation To The Performance Of Family Business In Makassar City, Indonesia, 17(6), 1-9.

Hidayat, M. (2011). Planning and Development Strategy (Case Study of Pangandaran Beach. THE Journal, I (1), 33-44.

Hofstede, G. (1986). Culture's Consequences, International Differences in Work - Related Values. London: Sage Publication.

Kartono, K. (1983). Pemimpin dan Kepemimpinan. Jakarta: Rajawali Pers. 
Kotter, John P. and Heskett, J. (2002). Corporate Culture and Performance. New York: The Free Press, A Division of Mac Millan, Inc.

Kreitner, Robert, Kinicki, A. (1995). Organizational Behavior, Third Edition,. USA: Richard D. Irwin Inc.

Molenaa, K. (2002). Corporate Culture, a Study of Form With Outstanding Consideration Safety. USA: Profesional Safety.

Robbins, S. P. (2003). Organizational Behavior. New Jersey.: Prentice Hall.

Sholihin dan Ratmono. (2013). Analisis SEM-PLS WarpPLS3.0. Yogyakarta: Andi Publisher.

Sugiyono. (2017). Metode Penelitian kuantitatif, kualitatif, dan $R \& D$ Cetakan ke- 19. Bandung: Alfabeta.

Tjala, A. (1989). Faktod Diri dan Lingkungan Kerja dalam Hubungannya dengan Produktivitas Kerja Karyawan Usaha Servis Elektronika di Kotamadya Ujung Pandang. Fakultas Pascasarjana IKIP Yogyakarta.

Zainal, H., Baharuddin, A., \& Farwita, S. (2019). Disiplin Kerja Karyawan Pada PT . Taspen ( Persero ) KCU Makassar Employee Work Discipline at PT . Taspen ( Persero ) KCU Makassar, 1(2), 101-106. 